\title{
Assessing the role of marketing in the provision of library and information services
}

\author{
Ezekiel Moenga Nyameti
}

Librarian, Kisii University, Kenya

*Corresponding Author: Ezekiel Moenga Nyameti

Email: ezekielmoenga80@gmail.com

\begin{abstract}
Marketing has a wide-ranging implication in its applications not only for profit generating organizations, but also not for non-profit organizations such as the libraries. The ultimate target of all academic libraries worldwide is user satisfaction and information services of which marketing helps to achieve in the utilizations and exploitations of library's resources. Nevertheless, there seems to be a growing acceptance amongst the wider information profession that marketing is essential in libraries and information services. The study adopted descriptive research design, and data was collected by use of questionnaires. The target populations were twenty nine thousand six hundred and five (29605) comprising of 20 library staffs. The sample of 394 respondents was selected. The researcher used questionnaires and interviews as the tools for data collection. The study indicated that provision of library and information services should be available for marketing practices. Based on the findings it was recommended that trainings workshops and seminars should be organized for the librarians to enlighten them on how to market the library and information services.
\end{abstract}

Keywords: Marketing, Library Services, Provision of library services, Library

\section{Introduction}

The adoption of marketing activities is increasing in academic libraries as a result of library strategic plans which assist clarification of key resources and services that should be promoted for optimal benefits of its users. Marketing is identified as a process of strategic planning that can increase the awareness and maximum usage of library resources and information services amongst potential users (Debbi, 2011). Since time immemorial, libraries foster knowledge and learning through providing access to information. As a result of increase and widespread use of the internet in recent years resulting to information proliferation, the traditional function of academic libraries as a physical collection of research materials is under threat (Madhusudhan, 2008). It is the responsibility of libraries to device means and ways to keep students to be aware of the shortcomings of unevaluated internet information. Librarians can promote and create awareness of library services through marketing information services and their users.

Information Technology has changed the spectrum of marketing information services in service delivery oriented organization such as libraries by impressing the need of its users to overcome the challenge, academic libraries with their embracing in the use of emerging marketing technologies as a strategic tool to connect users, (Kumar, 2015). Detlor and Lewis, (2006) posited that academic libraries are natural destination for students, faculty, staff, and researchers seeking information and serve as the repository for published information as well as the intermediary for acquiring material from the outside world. Academic libraries in India, have been comfortably serving their library information users by providing information resources that fulfill the needs of students and researchers. Where academic libraries are planned and managed by librarians who believed that they know best (Madhusudhan, 2008).
However, with information technology advancement to the marketing library information services to the needs for library information user their belief is under erosion can culminate to need for marketing library and information services. Librarians and information professionals have debated hotly on the need for marketing of library and information services where it was realized that librarianship has experienced rapid change and Information technology has created a new gateway for information services (Madhusudhan, 2008).

\section{Literature review \\ Library marketing}

According to Kotler, (2014) have been defines library marketing as a systematic orientation of all the operational functions in the library including information resource material processing, collection development, storage, information retrieval systems in order to meet the user's needs and wants. Furthermore, he reveals that marketing as a managerial process of planning, organizing, leading, and controlling and analyzing the market opportunities with the a view of choosing market positions that are geared towards the efforts of organizational members and using all other resources available to achieve the stated organizational goals.

Leisner (2002) views the academic library as a need which aims first to enhance quality information services and secondly aims at improving the perceived value of these information services to bring in the highest level of user satisfaction which enable the survival of the organization. Marketing concept that holds the key to achieving organizational goals consists in determining the need and wants of target market and delivering the desired satisfactions more effectively and efficiently than its competitors. The marketing strategies rest on four main pillars, namely target market, customer needs, coordinated marketing, and profitability. In totality, marketing strategies 
is a planned approach to identify and gain the support of users and develop appropriate services in a manner which benefits the users and in the case of academic libraries, further enhances the vision, mission and objectives of academic libraries. Marketing includes selling, advertising, physical distribution, sales promotion.

However, according to the UK Chartered Institute of Marketing, marketing is defined as "the management process responsible for identifying, anticipating and satisfying customer requirement profitably" (2010). From this definition, the key consideration is the customer and their informational needs. An effective marketer can accurately identify and anticipate their current and potential client's needs, and develop product or services to meet this need at the most appropriate time and value to those clients of the information Centre.

\section{Marketing of library and information services}

Ravichandran and Babu (2008) define marketing as the process of planning, pricing, promotion and distribution of library products to create exchanges that satisfy the library and its users (clients). Irving (1992) also observes that it is the market place for new insights into marketing library services to fulfill certain criteria relating to convenience, ease of use, perception of balance between cost and value, choice and new ways of doing existing tasks.

Weingard (1995) noted that in marketing library and information service is a process of exchange and a way to foster the partnership between the library and the users. In this view, it is therefore important to note that marketing library and information services includes user priorities, their expectations, individuality, responsiveness, relationship, quality of service, the professional skills, competence and value added services.

Equally Ranganathan explains it is no wonder that when the library has been extending its scope, changing its outlook and altering its very character and functions, there should not be adequate understanding as to what has been going (McCarthy Madden, 2009, p.7). Therefore, without strategic marketing and the consequent marketing method, library users are unlikely to be fully aware of what the library can offer them. As highlighted by Pantry and Griffiths (2009), marketing influences user behavior within library and information service, but user behavior also in turn influences marketing. Woodward, (2009) the library's equivalent of a business' bottom-line is the library mission statement. Marketing is not used as a sales tool for libraries but as a way to understand user needs and improve awareness of appropriate services through successful communication. Marketing in libraries is not a new concept; librarians have been doing this for some time (Duke and Tucker, 2007).

Professionally, marketing is frequently cited as unpopular among library staff (Lindsay 2004; Singh 2009). Kumbar (2004) gave suggestions why there may be a negative view towards marketing in libraries, citing reasons such as the believe that marketing is viewed as manipulative, unprofessional and unnecessary; it is misunderstood due to lack of marketing, training and education; libraries lack marketing funds and there is a reluctance to use techniques originally developed for the private sector.

Boden and Davis, (2006) explains that there seems to be growing acceptance amongst the wider information profession that marketing is essential in libraries and information services; and that marketing your library service should not be considered a luxury but a necessity. This transformation of view may be partly due to the pressures from the current economic climate; shrinking budgets, and uncertainty surrounding the future of libraries and librarians. Equally, there is need to investigate the impact of market library and its information services in academic libraries (Parry, Laing and Stephens, 2009).

Indeed, the acceptance of marketing in libraries may also be partly due to technological and society changes which have impacted on libraries due to an increasing number of alternative information sources. Currently, potential library users have become more reliant on the internet, thus it is becoming more critical than never for librarians to proactively market information services (Cheney, 2007).

Therefore, there is need for marketing libraries to ensure users understand the added value a library and its librarians can give over freely available online information sources. According to Dubicki, (2007) records that there is a growth in a number of jobs advertised for librarians with qualifications and/or experience in marketing, further emphasizing its importance in today's libraries. The existing literature on marketing in academic libraries has focused on marketing initiatives and activities - print marketing materials such as posters, leaflets and tip sheets (Gaffney and Jones, 2007; Peters and Fiander, 2004); face to face marketing such as Fresher's Fairs (Bury and Phillips, 2005); and use of innovative technologies to promote online library services (Oxford, 2009).

This shift in approach to marketing in academic libraries support Kotler and Fox's (2000) developmental model demonstrating the evolution of marketing in educational institutions: marketing is unnecessary: marketing is promotion, marketing is segmentation and marketing research; marketing is positioning, marketing is strategic planning, marketing is enrolment (relationship) management. The stages of evolution seem to concur with the development of the perception of marketing within the library profession. Circle and Bierman (2009) confirm this transition in library marketing, demonstrating that marketing has progressed from being used purely as a promotional tool; 'the days when marketing was thought to be posters and fliers is over which has influenced academic libraries to adopt marketing.

\section{Research methodology}

The study adopted descriptive research design. This design is important, because it enabled the researcher to explain the situation the way it is. In this study, the target population was 29605 students and 200 staffs working in 
the library. Out of 29605 student respondents, 394 were selected as the sample population for students and 20 staffs who were interviewed. The study adopted on Yamane Taros (Israel 1997) sampling formulae to calculate the sample size $n=\frac{\mathrm{N}}{1+\mathrm{N} \times(\mathrm{e})^{2}}$

Where; $n=$ sample size, $\mathrm{N}=$ the population size, and $\mathrm{e}=$ sampling error or margin of error $-+10 \%$

From the above formula, the sample size for the study was derived as follows: $n=\frac{N}{1+N(e)^{2}}$

While sampling students, the researcher adopted stratified sampling technique strata represented by their year of study and program me enrolled. Library staff members were sampled using purposive sampling techniques because it would give every individual with relevant information to participate. It was convenient because the respondents were scattered. Sampling is a research technique used for selecting a given number of subjects from a target population as a representative of that population. Questionnaires and interviews were used in data collection.

Data was analyzed using statistical methods where classifications and tabulations were used to summarize classified data. The raw data from the questionnaires was exported into Microsoft excel for easy analysis. Microsoft excel was used because it create appropriate figures and charts to identify key trends, similarities and differences in the data.

\section{Data analysis}

The researcher sought to examine the role of library information services. The variables under these findings are divided from data reviewed and show how library services are identified with the role.

Table 1: Role of marketing library information

\begin{tabular}{|l|c|c|c|}
\hline & N & Mean & $\begin{array}{c}\text { Std. } \\
\text { Deviation }\end{array}$ \\
\hline $\begin{array}{l}\text { Create a high level of } \\
\text { customer satisfaction }\end{array}$ & 376 & 3.67 & .838 \\
\hline $\begin{array}{l}\text { To bring about desired } \\
\text { quality objectives of the } \\
\text { library }\end{array}$ & 376 & 3.96 & .652 \\
\hline $\begin{array}{l}\text { To satisfy the needs of } \\
\text { library users }\end{array}$ & 376 & 4.03 & .918 \\
\hline $\begin{array}{l}\text { To promote high for } \\
\text { usage of information } \\
\text { resources utilization }\end{array}$ & 376 & 3.13 & 1.481 \\
\hline Valid 376 (listwise) & 376 & & \\
\hline
\end{tabular}

\section{Field data (2016)}

The study show that to satisfy the needs of library users had highest mean of 4.03 followed by to bring about desired quality objectives of the library at 3.96 followed by to create a high level of customer satisfaction 3.67 and the lowest show that to promote high for usage of information resources utilization had 3.13 as shown in table 1 .
The study findings revealed that to satisfy the needs of library users is the most marketing influence in library information services. The study findings show that there was statistical increase in standard deviation as the mean decrease $1.481,918,838$, and 652 , respectively which indicated that the role of library information is influenced by marketing strategies.

The researcher also categorized the role of library information and sought to examine the level of influence by marketing strategies. The study findings recommended that there was need to promote high usage of information resources utilization in services provisions. This showed that study of Zeithaml, Bitner and Gremler (2009) that identified the unique services which make them to take apart when compared to available resources: Intangibility. The service offered cannot be produced in advance; it must be produced.

The study sought to examine the role of library information services at academic library. The study shows that library information help users to develop the information literacy from resources had the highest mean at 3.01 followed by ensure the optimum use of information materials at 2.85 , followed by save library from the devaluation had 1.89 and to enlighten users from the internet had 1.56 respectively. The study standard deviation also indicated that 1.517 was the highest deviation from normal distribution.

Table 2: Role of library information services

\begin{tabular}{|l|c|c|c|}
\hline & N & Mean & $\begin{array}{c}\text { Std. } \\
\text { Deviation }\end{array}$ \\
\hline $\begin{array}{l}\text { To enlighten users from } \\
\text { the internet }\end{array}$ & 376 & 1.56 & 1.087 \\
\hline $\begin{array}{l}\text { Save library from the } \\
\text { devaluation }\end{array}$ & 376 & 1.89 & 1.303 \\
\hline $\begin{array}{l}\text { Ensure optimum use of } \\
\text { information materials }\end{array}$ & 376 & 2.85 & 1.517 \\
\hline $\begin{array}{l}\text { Help users to develop the } \\
\text { information literacy } \\
\text { library } \\
\text { from resources }\end{array}$ & 376 & 3.01 & 1.483 \\
\hline Valid 376 (listwise) & 376 & & \\
\hline
\end{tabular}

\section{Field data (2016)}

The study revealed that marketing strategy had influence to users to develop the information literacy from library resources.

The researcher looked at examine the role of library information services provided. The market strategy was identified with balance shrinking funds in order to attract donor funding bodies, uphold the dictum that information is power, introduce cutting edge of IT systems in library and provide conducive reading environment for users to study.

The results indicated that role of library information provides conducive reading environment for users to study with the highest mean of 3.24 followed by Introduce cutting edge of IT systems in library which had 2.93 which was followed by balance shrinking funds in order to attract 
donor funding bodies 2.66 and uphold the dictum that information is power had 1.78 respectively.

The study findings revealed that that the role of library information provides favorable reading environment for users to study implied highest influence. The study also recommended that to uphold the dictum that power information in the library information services provided. The study confirms that marketing strategies had influence in library information provided.

Table 3: Role of library information services

\begin{tabular}{|l|c|c|c|}
\hline & N & Mean & $\begin{array}{c}\text { Std. } \\
\text { Deviation }\end{array}$ \\
\hline $\begin{array}{l}\text { Balance shrinking attract } \\
\text { donor funding bodies }\end{array}$ & 376 & 2.66 & 1.473 \\
\hline $\begin{array}{l}\text { Uphold the dictum that } \\
\text { power information }\end{array}$ & 376 & 1.78 & 1.240 \\
\hline $\begin{array}{l}\text { Introduce cutting edge of } \\
\text { IT systems in library }\end{array}$ & 376 & 2.93 & 1.557 \\
\hline $\begin{array}{l}\text { It provide conducive } \\
\text { reading environment for } \\
\text { users to study }\end{array}$ & 376 & 3.24 & 1.232 \\
\hline Valid N (listwise) & 376 & & \\
\hline
\end{tabular}

\section{Field data (2016)}

The study findings show that introduce cutting edge of IT systems in library 1.557 followed by Balance shrinking funds in order to attract donor funding bodies at 1.473 followed by uphold the dictum that power information at 1.240 and it provide conducive reading environment for users to study at 1.232 respectively. The standard deviation show significant increase as marketing strategies decrease implied that the role of library information is influenced by marketing strategies.

\section{Conclusion}

The researcher also categorized the role of library information and sought to examine the level of influence by marketing strategies. The study findings recommended that there was need to promote high usage of information resources utilization in services provisions. This recommend for the study of Zeithaml, Bitner and Gremler (2009) that identified the unique characteristics of utilization services which make them to take apart when compared to resources available: intangibility. The service offered cannot be produced in advance; it must be produced.

The study concluded that marketing strategies were adopted by library to market its information resources and services at Kisii university library. The study revealed that quick advances in digital knowledge have provide the library other resources to the users with considerably more options thus libraries were facing stiff competition from search engines like internal strategy on goggle strategy.

\section{Recommendations}

The study established the influence of marketing in academic library services and recommended that most of the respondents should accept the need for marketing of library for information. The asked the respondents on whether they understand marketing especially formation services practiced in academic and recommended that most of the respondents should understand marketing services. The study asked on whether library needs marketing its information services and recommended that there was need for marketing because the university library needs to market its information services.

\section{Suggestion for other study}

The study recommended for future study to focus on the provision of library information on performance of academic libraries. The study should investigate whether data on provision of library and information services available for marketing practices. Another study can also be conducted marketing practices on service delivery based on role of marketing strategies that is adapted for enhancing marketing library and information services.

The study to be conducted to enhance marketing library and information services on students' performance. Librarian suggested a study to market library services with good public relations, good and mutual understanding between the library and users.

\section{References}

1. Austin D (2012) the Division of Statistics, Scientific Computation, The University of Texas.

2. Attebury, R.I. and Finnell, J. (2009) What do LIS students in the United stated know about liaison duties? New Library World, 110(7/8): 325-340.

3. Attebury, R. I. and Finnel, J. (2009). What Do LIS Students in the United States Know about Liaison Duties? New Library World, 110(7/8): 325-340

4. Agarwalla, S., Seshadri, B., and Krishnan, V. R.. Impact of Guna s and Karma Yoga on Transformational Leadership. $J$ Hum Values 2015;21(1):11-22.

5. Begum, S.S.N. Total quality management in the academic library. Library Philos Pract [online]. 2003;5(2): [Accessed: 30 May 2011]. Available at:<http://www.webpages.uidaho.edu/ mbolin/begumtqm.html $>$.

6. Becher M. L. and Flung, J. L. Using Student Focus Groups to Inform Library Planning and Marketing. Coll Undergrad Libr 2005;12(1/2): 1-8

7. Biggam, J. (2011). Succeeding with your Master's Dissertation: A step-by-step Handbook, 2nd edn. Berkshire: Open University Press.

8. Boden, D. and Davis, L. Developing a Marketing Mindset. Libr Inf Update 2006;5(5):38-39.

9. Busari, ismail, Taiwo, Ayanko Busari, Ismail Taiwo, Ayankola, Ibrahim Ayandare, Ladipo, Sunday Olusola (2015) who conducted a study on the analytical approach to the effective marketing of library and information products and services in Academic Libraries in Canada.

10. Broeckelmann Philipp Austrian Economics as a Basis for a General Marketing Theory: Potentials and Limitations Austrian economics, Am Econ Rev 2004;35(1945)no. 4:519530 .

11. Brewerton, A. (ed.) (2008). Marketing Library Services - a SCONUL Working Paper. London: Society of College, National and University Libraries.

12. Broady-Preston, J. (2008) DS32620: Marketing of services.3rd edn. Aberystwyth: Open Learning Unit 
13. Broady-Preston, J. (2008). DS32620: Marketing of Services. $3^{\text {rd }}$ Edn. Aberystwyth: Open Learning Unit.

14. Broady-Preston, J. and Felice, J. (2006). Customers, Relationships and Libraries: University of Malta - A Case study. Aslib Proceedings, 58(6):525-536.

15. Broady-Preston, J. and Preston, H. (1999). Demonstrating Quality in Academic Libraries. New Library World, 100(3):124-129.

16. Brophy, P. (2005). The Academic Library, $2^{\text {nd }}$ Edn. London: Facet.

17. Bryman, A. (2008). Social Research Methods, $3^{\text {rd }}$ edn. Oxford: Oxford University Press.

18. Bury, R.and Phillips, M. (2005). 'Any time, Any place, Anywhere': a Fresh approach to Marketing at Edge Hill. SCONUL Focus [online]. 36, pp. 23-25 [Accessed: 13 January 2010].

19. Cheney, K. (2007) Marketing law libraries: strategies and techniques in the digital age. Legal.

20. Cook, S. (2008). Customer Care Excellence: How to Create an Effective Customer focus, $5^{\text {th }}$ edn. London: Kogan Page.

21. Creaser, C. (2006). One size does not fit all: user surveys in academic libraries. Performance Measurement and Metrics, 7(3):153-162.

22. Creswell, J.W. (2003). Research Design: Qualitative, Quantitative and Mixed Methods Approaches, $2^{\text {nd }}$ edn. Thousand Oaks: SAGE.

23. Debbi A. Smith (2011) Strategic Marketing of Library Resources and Services, Coll undergrad libr (18), Iss. 4,2011, Newyork USA.

24. Dittoe, W. (2006) Seriously cool places: the future of learning-centred build environments.

25. Dubiciki E. Duke, L.M and Tucker, T. (2007). How to Develop a Marketing Plan for an Academic Library. Technical Services Quarterly, 25(1):51

26. Duke, L.M. and Tucker, T. (2007) How to Develop a Marketing Plan for an Academic Library.

27. Ewers, B. and Austen, G.(2004), "Market orientation: a framework for Australian university library management", in Gupta, D. K.(Ed.), An International Review of Marketing in Library and Information Centers, IFLANET, available at: October2012)

28. Evans, J. A. (2008). Electronic Publication and the Narrowing of Science and Scholarship. Science, 321(5887): 395399.https://doi.org/10.1126/science.1150473.

29. Faibisoff, S and Ely D. (2006). Information and information needs.

30. Finney, J. and Warnaby, G. (2004). Developing a Marketing Orientation at the British Library. SCONUL Focus [online]. 32, pp. 42-44

31. Gillham, B. (2007). Developing a Questionnaire. $2^{\text {nd }}$ edn. London: Continuum International.
32. Glynn, T. and Wu, C. (2003). New Roles and Opportunities for Academic Library Liaisons: a Survey and Recommendations. Ref Serv Rev 31(2):122-128.

33. Gorman, G.E. and Clayton, P. (2005). Qualitative Research for the Information Professional, $2^{\text {nd }}$ edn. London: Facet.

34. Gaffney, T. and Jones, J. (2007) Advertising and information services - a partnership success story. SCONUL Focus [online].40,:53-56 [Accessed: 17 May 2011]. Available.

35. Grönroos, C. (2007). Service Management and Marketing: Customer Management in Service Competition. $3^{\text {rd }}$ edn. Chichester: John Wiley.

36. Gupta, D.K. and Jambhekar, A. (2002) What Is Marketing in Libraries? Concepts, outlook; Munich: K.G Saur Verlag Publishers.

37. Gupta D.K Koontz C., and Massisimo A., (2013) Marketing library and information service; A Global.

38. Gupta Dinesh K. (2010) Marketing Library and Information Services, Department of Library and Information Science, Vardhaman Mahaveer Open University, Kota, India, Encyclopedia of Library and Information Sciences, Third Edition DOI: 10.1081/E-ELIS3-120044552.

39. Gbaje, E. S. (2007). Provision of online information services in Nigerian academic libraries. Nigerian Libraries: J Niger Libr Assoc, 40. Retrieved from http://eprints.rclis.org/11902.

40. Griffiths, J. R., and Brophy, P. (2005). Student searching behavior and the web: use of academic resources and Google. Libr Trends 53(4): 539.

41. Hernon, P. and Altman, E. (2010). Assessing service quality: satisfying the expectations of library customers. $2^{\text {nd }}$ edn. Chicago: Am Libr Assoc.

42. Hiller, S (2001). Assessing User Needs, Satisfaction, and Library Performance at the University of Washington Libraries.

43. Huwe, T.K. (2007) Building digital libraries: inquiry-based learning and library design. Computers in Libraries, 27(5):3436.

44. Ismail Ali Yusuf Hassan (2013) Customer service and organizational growth of service enterprise in Somalia International Educational Research ISSN-1: 2307-3713, vol. 2 no. 2 October 2013 Simad University, Mogadishu, Somalia.

45. Jose, A. and Bhat, I. (2007). "Marketing of library and information services: a strategic perspective", $J$ Business Perspect 11 No.2,pp.23-28.

46. Kanaujia, S. (2004), "Marketing of Information Products and Services in Indian RandD Library and Information Centers.

How to cite this article: Nyamti.E. M. S, Assessing the role of marketing in the provision of library and information services, Indian j Libr Sci inf techno. 2018;3(2):79-83 